\title{
Consideration of Computer Mediated Education: A Critique
}

John W. Murphy

Arkansas State University

Presently technology is proliferating throughout the world at an unprecedented rate. The computer, to cite a prime example, has made its way into the home, farm, factory and of course the classroom. Great problem-solving claims are made by those who favor this increase in computerization. However, the philosophical underpinnings of technology are not currently being given serious attention, consequently its deepest social impact remains obscured. Without an examination of the technological "world-view," technicized images of the classroom, learning, and students which accompany it may go undetected (Ihde, 1977, pp. 139-143; Thde, 1979, pp. 3-39). The aim of this paper is, therefore, to reflect philosophically upon the ground of technology, and to steer the discussion towards an appraisal of educational practices which draw from a more general technological world-view. It will be argued that the prevailing technology portrays social existence quite negatively and stifles the critical and creative style of learning that most educators extoll.

\section{The Deanimation of Social Life by Technology}

The central difficulty with technology is that it denies the originating "lifeworld." This situation resembles that which Husserl (1970, pp. 3-16) identified in the mid-1930s as precipitating a "crisis" in European science, only now "lived experience" is deprecated further. Technology, in other words, spawns a completely rationalized science, devoid of the enthusiasm introduced by Einstein, Planck, Heisenberg, and Bohr. As Merleau-Ponty (1964, p. 110) argued, the lifeworld (Lebenswelt) is the domain which is deployed by human expressivity and it is, therefore, the source of meaning for all phenomena. The lifeworld is the living presence to which all persons inhere; it is the social fabric inscribed by human praxis (p. 135).

This living world embodies the actions which illustrate empirical facts to be symbolic realities. What this means is that the world has significance which is linguistically and perceptually instituted, and is not comprised of obtrusive things and places as is typically assumed. The world's meaning is elusive; it shifts with the movement of the human spirit. Most important is that the world is not objective in the Cartesian sense, but is a world for someone. All knowl- 
edge, stated simply, is mediated by the constitutive activity of human experience and represents neither crudely realistic events nor an ideal Kantian "in-itself." The meaning that the world has is a social product, as human action is at the heart of all events. The world, as Husserl (1970, p. 113) pointed out, is a "meaning-construct" (Sinngebilde).

As should be immediately noted, when the world is envisioned to be a lifeworld the significance of human activity cannot be diminished, as in theories which maintain that objects have a self-same identity, immune to the influence of human intentions. When conceived objectively a phenomenon's identity is not dependent upon human action and subsequently individuals are unable to treat it creatively. It is this creative tendency that technology inadvertently suppresses.

The central trait of technology is the rationalizing of existence in a particular manner (Habermas, 1970, pp. 363-387; Heidegger, 1967, pp. 14-15; Marcuse, 1964, p. 32). Technology displaces human action and "deanimates" social life by inserting its own axioms at the center of existence, and since technology requires that specific principles be given such a seignorial status, the result is what Ellul (1964) calls "technological slavery." This does not mean, as some critics of technology suggest, that individuals are enslaved merely because they must work with machines, but rather because the logic of technology is assumed to be objective, ahistorical, and thus undaunted by existential contingencies (Caldwell, 1981, pp. 257-270; Ihde, 1982).

What this means is that a functional image of social existence is promoted, as exemplified by the work of Talcott Parsons (1966, pp. 1629). This social imagery portrays order to be "centered" (Luhmann, 1970, pp. 137-153), and when a society is centred it is believed that order can originate only from a source that is untrammeled by human experience. Luhman argues that the Western philosophical tradition has had a penchant for conceiving order in this manner, although a technological rendition of society epitomizes this trend.

As a result, human action is not envisioned to be self-directing. Instead the history traced by human inventiveness is perceived to be nothing more than the residue left behind by technology (Habermas, 1971, p. 48). What Habermas means by this is that since human action (energy) merely supports an imperious system, behavior is considered worthwhile only when its social function is adequately performed. Simply stated, human action receives its identity as a result of maintaining the social system, and thus is not provided with the latitude to be a source of antagonism to this order. Marcuse (1964) shows that this results in persons living in a "one-di- 
mensional" world where the dominant values and norms of a society are treated as inherently legitimate, while all opposition to them is eviscerated. The only actions that are evaluated positively are those that acquiesce to authority and unquestioningly mimic traditional modes of behavior.

This obfuscation of the lifeworld culminates in an externalized locus of social order and the belief that persons are living in a social system that exists sui generis. A social ontological realism prevails according to which the system is the only thing considered real, with everything else deriving from it. As Stark (1963, pp. 2-3) puts the matter, this image of social existence requires that the social system be understood to supply individuals with their identity, and therefore they are forever indebted to this source of meaning. The general aim of this rendition of social life is to ensure that all persons fulfill their ambitions within the parameters established by the system, and not that they should exist autonomously on the basis of their own judgments.

Technological education takes place in the shadow of such technological rationality. Although this approach to education is certainly related to the use of machinery which mediates the educational process, these apparatuses are merely an outgrowth of a philosophy which equates technological rationality with reason. Yet when technological thinking is identified as the highest form of rationality many problems result: (a) Technological ratiocination is viewed as synonymous with reason, while all other forms of thought are dismissed as tainted with emotionalism. (b) Calculation is understood to be the most effective mode of communication. (c) Worldly phenomena are treated as resources to be managed, thus deanimating human action. (d) And the social world is conceived to be a self-equilibrating machine within which persons exist (Lenk, 1973; Murphy, 1984). In this sense, social life is provided with the facade of an objective identity that must be manipulated and mastered. Because technology penetrates to the core of the human spirit to instill reason, wonder (thaumazein), as Aristotle called it, is purged from the world. Thus the mystery associated with thinking and learning is eliminated from education (Heidegger, 1966, p. 55). Centrally important is that although mechanized learning may routinize education, technology or the logos of technique, may accomplish this long before any machines are actually introduced into the classroom. The world-view of technology may therefore ensure that educational technology creates rather than responds to the needs of students. This manipulation can be exemplified in the following ways.

\section{Computerized Education and the Culture of Technology}

1. Technology tends to atomize or fragment the learning process, resulting in what Sartre (1977, pp. 166-169) calls "serialization." Most 
often this is referred to as individualized learning. Yet even when it is undertaken collectively (for example, through the use of TV monitors), the result is the same: persons must adjust to a learning device, closely monitor its instructions, follow its commands, and supply appropriate responses at the right time. As the movements of a student and the learning device become interlocked, the student's intentions are subsumed by the built-in learning process.

No "play-space" is present between an instrument's instructions and a student's response (Strauss, 1963, pp. 139-158); instead all personal choices are realized after they are legitimized by a machine and imprinted cognitively. While participating in this process students are literally "plugged" into the knowledge that is acquired through a type of technological forced feeding. And when learning is approached in this manner the dynamism that is possible in a classroom can never be experienced. For example, knowledge can never be challenged, expanded, and its symbolic nature revealed, as is possible when information is bandied about a classroom. Moreover, in computer mediated learning all challenges to technological rationaliliy are defined as irrational, as even the liberating potential of conflict is denied to students.

2. Technological learning relies on discourse that is thoroughly monological (Habermas, 1970, pp. 114-148): Information is perceived to have a single source, to be self-legitimating, and to therefore possess indubitible integrity. This occurs because the origin of knowledge is experienced by students as ahistorical, which is to say unaffected by the parties that are exchanging or using this information. As Habermas (p. 131) argues, communication is monological when it (a) originates from a source that is not thought to be contingent, (b) is imparted by an authority that allegedly represents Reason, and (c) is assumed to be providing rationality where none is believed to exist.

Technological pedagogy epitomizes the monological style of discourse. The computer presents information which is not susceptible to critique or interrogation, and therefore the student can only record and not actively analyze what is to be learned. This method of communicating eliminates any ambiguity from the process of identifying a correct answer, and systematically reduces the need for students to learn how to classify and generalize. A priori categories are merely mastered and data placed into them, without students having to understand or, more importantly, participate in structuring this process.

3. Technology merely allows for what Horkheimer calls "instrumental" learning, the aims of which are to process information rapidly, identify relationships, and increase a person's response time. Although information passes before one's eyes quickly, as in video 
games and speed reading classes, Horkheimer (1974, pp. 23ff) suggests that little else is accomplished. All that is fostered is a type of "means-end" rationality, as students learn to follow premises to their logical conclusions as expeditiously as possible. And throughout all this it is assumed that a system of reason underpins the logic of these relationships. Quickness of response is considered to be a valid index for measuring learning because efficiency and accuracy are presumed to be at the heart of intelligent behavior. It is simply assumed that reason exists in the world and that a gifted person should be able to discover it faster than those who are less talented.

4. The knowledge that is conveyed technologically is acquired primarily through continued manipulation or practice. Technology, as Luhmann states, "unburdens decision making." Knowledge appears as if it arrives on the scene fully developed, as "either/or" options that become understood through repetition, and learning is assumed to have occurred when students are able to apply this logic to concrete situations, through problem solving exercises. In computer mediated learning knowledge is merely adopted and implemented, without being thoroughly scrutinized. This is not the activistic style of practice advocated by John Dewey, which requires that personal or pragmatic motives serve to determine the utility of knowledge. Instead information is valued on the basis of clarity, reproducibility, and immediate social utility, as opposed to its thought provoking character.

5. Technological pedagogy offers a passive image of human existence. Technology portrays social life as if it exists absolutely, as a fixed set of behavioral and cognitive options. The implicit aim of education, accordingly, is to introduce students to these laws and norms so that social competence is acquired. Students are therefore inadvertently told throughout their education that the recognition of and adjustment to this unquestioned reality is highly valued and handsomely rewarded. And although it is certainly not the aim of technology to stifle divergent thinking, independence of thought is dampened when information is divorced from human action.

Yet maybe more important than this is the asocial image of social life that is suggested by technological learning. Because technology tends to "rationalize" learning, thereby eliminating interpretation as a central component in education, social fragmentation is promoted. Because technology does not entail knowledge acquisition as a "purposive-rational activity," a matter of decision and interpretation, it is assumed that one person alone, involved in a "subject-object relation" to information, can discover universal truth (Apel, 1979, pp. 15-16). On the other hand, when learning is understood to be a thoroughly interpretive activity, and not merely con- 
cerned with perceptual or logistical acuity, the issue of intersubjective validity is raised. That is, interpretation presupposes the possibility of a variety of interpretations, a community of interpreters, the need to recognize all interpretations, since none by definition is absolute, and a procedure for merging these interpretations into a common body of knowledge. In short, interpretive learning recognizes both the self and others as central to acquiring information, instead of treating education as an asocial process which stresses the mimicry of facts.

Interpretation is both similar and different from logic and perception. The similarity stems from the fact that the ability of persons to visualize and categorize information is presupposed by interpretation. Interpretation, however, is different from logic and perception in that the structure of interpretation arises out of human action, while the dimensions which are utilized by perception and logic are typically treated as antedating the acquisition of knowledge. Yet interpretation does not result in solipsism and relativism simply because interpretive acts are accompanied by alternative renditions of understanding which are tacitly assumed. Hence interpretation illustrates the ability of persons to recognize interpretive differences and to establish a legitimate basis for social order (Luhmann, 1982, pp. 353-355). What technological learning accomplishes is to eliminate interpretation from education and, accordingly, to atomize social life. Because technology stresses the acquisition and not the generation of knowledge, the critical reflection which illustrates the epistemic limits that both separate and unite varying interpretations is impossible.

\section{A Human Ground for Technology}

Thus far it has been suggested that technological education can severely limit learning, since merely mimesis and not the critical accumulation of information is emphasized. Nevertheless, it is not inevitable that the use of technology by educators must have undesirable consequences. Education is stifled only when an autonomous image of technology is permitted to prevail, thereby reducing the significance of human action in acquiring knowledge. Accordingly technological education does not have to be abandoned, yet a more responsible rendition must clearly be developed. This type of responsibility, however, can only be realized if a ground of technology is specified that prevents it from appearing to be autonomous and in opposition to human action. Education must be provided with a human ground; otherwise the positive aspects of technological pedagogy which educators usually extoll may never be realized.

This technological "world-view" is more pervasive than the techniques which serve as a focus. Indeed, often those who are critical of the dehumanizing effects of technological learning are still enam- 
ored of this type of thinking (Landers, 1971; Rosove, 1972; Davies, 1982). Merely becoming a modern Luddite is not sufficient to insure that human action is able to penetrate to the core of the "reality" advanced by technology, thus opening the world as a horizon of interpretive possibilities. Instead, the social imagery which technology poses must be seriously questioned so that freedom is not sacrificed for the sake of maintaining social order. It is not enough for persons to want to control technology, or believe that it is just a tool, but rather the autonomy of this modality of conceptualizing the world must be undercut. In this way technology is placed in the service of humanity (Husserl, 1970, p. 17). Moreover, merely controlling the application of technology is not at all similar to technology having a humanly inspired orientation (Heidegger, 1969, p. 40). Technology may be applied, for instance, only within a domain that is technologically appropriate, as specified by "technological rationality. This type of technological morality," as Ellul calls it, must be overcome if humans are to be self-directing.

Most important when establishing this new ground is to recognize that the world is neither subjective nor objective, but a dimension that subtends this differentiation. Technology employs this Cartesian distinction and therefore projects an image of an objective world that is allowed to control individual behavior. Yet if technology is to ever be responsible to its creators, it cannot be perceived as immune to existential claims. Technology must also be understood to emanate from what Merleau-Ponty (1968, pp. 130-135) calls the "chiasm," the intertwining of objectivity and subjectivity that is human action. Education must no longer be undertaken in terms of those ancient maxims which claim to provide access to ideal or timeless truths. As a result of their education persons must not be "led out" of the world but out of darkness and obfuscation which inhere in human existence. Accordingly, it should be stressed that all knowledge is mediated by human presence. The world is not an extended thing, but has a humanly inscribed texture-a thickness introduced by deep commitment. Thus knowledge is completely immersed in meaning, in "flesh" (Merleau-Ponty, 1968, p. 127), and education should demonstrate the need to establish truth on the basis of this corporeal action (Nietzsche, 1954, pp. 152-153). Education should return persons to their lived-world, as opposed to starting them on a journey which eventually requires that they deny their existence.

This world, however, is not the mundane world, the one which naive subjects must mollify. It is the world that always exists for someone, a world that individuals are able to call their own. If it were not the case that the world is mediated by human action or experience, then it would have a status as infamous as Kant's "in-itself" and remain unknown and basically useless. The world that education should 
resurrect is the "lived-world," the pre-objective world that is sustained by human praxis. All education must be understood to be an interpretive process which emphasizes the mastery of inquiry and not merely the acquisition of fixed principles. Since technology is also implicated in the opacity of the lived-world, education must breathe life into it and give it meaning.

Breathing life into technology may be seen by some to be more of a problem than providing a solution to the autonomy of technology, for as Heidegger said: only a God is able to save humanity from the wrath of technology. But Heidegger also said: Gods do not dwell above the earth, but in the "Holy," or the "clearing" revealed by Dasein (Heidegger, 1962, p. 294). In this sense, enlivening technology with human action may be difficult, yet it certainly is not something that persons are inherently incapable of doing. As humans recognize their indwelling in the world, and that they carry their destiny in their own hands, they can establish the domain where technology resides. The salvation of technology rests at the center of human existence. Any problem with technology must be settled within the dimensions specified by human action. With this in mind, Holderline's lines take on renewed meaning: "But where danger is, grows the Saving power also" (Heidegger, 1967, p. 35).

As a result of this theoretical shift technology assumes what Marcuse (1964) refers to as an "aesthetic," or "desublimated," identity. This means that technology does not supply its own parameters for identifying information which are able to hold the learning process hostage. Technology no longer has the capability to determine what is real; instead, technology rests on a base of human action and owes its significance to this expressive dimension, without which it would only resemble formless content or contentless form. Yet when understood to originate from human action technology cannot legitimately turn against its creators, since this type of autonomy cannot be sustained. Accordingly technology can be used critically, without our having to fear that it will dictate learning.

From an educational perspective, merely adding more technology to an already abstract teaching strategy will not make it socially responsible. Educators need to become aware of the philosophical underpinnings of technology for fear of stifling criticism, inhibiting divergent thinking, promoting a non-reflective attitude on the part of students, and conveying an asocial image of social existence. An interrogation of the ground of technology would involve educators taking care not to foster inadvertently a technicist mode of learning through their use of technology in the classroom. It would invoke a deeper sense of pedagogical commitment. 


\section{References}

Apel, K-O. (1979). The common presuppositions of hermeneutics and ethics: Types of rationality beyond science and technology. In J. Sallis (Ed.), Studies in phenomenology and the human sciences (pp. 35-53). Atlantic Highlands, NJ: Humanities Press.

Caldwell, R.M. (1981). Computers and curriculum-Promises and problems. In The Institute for Educational Leadership (Ed.), Technology and education (pp. 257-270). Washington, DC: Institute for Educational Leadership.

Davies, J.J. (1982). Linking computer technology and learning: The case for human teachers and computer learners. Educational technology, 22(10), pp. 13-17.

Ellul, J. (1966). The technological society. New York: Vintage Books.

Habermas, J. (1970). Toward a theory of communicative competence. In H.P. Dreitzel (Ed.), Recent sociology, No. 2 (pp. 114-118). New York: Macmillan.

Habermas, J. (1971). Knowledge and human interests. Boston: Beacon Press.

Heidegger, M. (1962). Letter on Humanism. In Barrett, W. and Aiken, H.D. (Eds.), Philosophy in the twentieth century, Vol. 3 (pp. 270-302). New York: Random House.

Heidegger, M. (1966). Memorial address. In Heidegger, M., Discourse on thinking, (pp. 43-57). New York: Harper and Row.

Heidegger, M. (1967). Die Frage nach der Technik. In Heidegger, M., Vorträge und Aufsatze, Teil 1. (pp. 5-36). Pfulligen: Verlag Günther Neske.

Heidegger, M. (1969). The principle of identity. In Heidegger, M., Identity and difference (pp. 23-41). New York: Harper and Row.

Horkheimer, M. (1974). Critique of instrumental reason. New York: Seabury.

Husserl, E. (1970). The crisis of European sciences and transcendental phenomenology. Evanston: Northwestern University Press.

Ihde, D. (1977). Experimental phenomenology. New York: G.P. Putnam's Sons.

Ihde, D. (1979). Technics and praxis. Dordrecht: D. Reidel.

Ihde, D. (1982). The historical-ontologial priority of technology over science. Paper presented at the International Conference on Philosophy and Science in Phenomenological Perspective. Buffalo, New York.

Landers, R.R. (1971). An approach to humanizing education through technology. Eductional Technology, 11(6), p. 9-11.

Lenk, H. (1973). Technokratie und Technologie: Notzen zu einer ideological Diskussion. In Lenk, H. (Ed.), Technokratie als Ideologie (pp. 105-124). Stuttgart: Verlag W. Kohlhammer.

Luhmann, N. (1970). Soziologische Aufklärung. Opladen: Westdeutsche Verlag.

Luhmann, N. (1982). The differentiation of society. New York: Columbia University Press.

Marcuse, H. (1964). One-dimensional man. Boston: Beacon Press.

Merleau-Ponty, M. (1964). Sense and non-sense. Evanston: Northwestern University Press.

Merleau-Ponty, M. (1968). The visible and the invisible. Evanston: Northwestern University Press.

Murphy, J.W. (1984). Technology, humanism, and death by injection. Dialogos, $44,165-175$. 
Nietzsche, F. (1954). Thus spoke Zarathrustra. In Kaufman, W. (Ed.), The portable Nietzsche (pp. 103-439). New York: The Viking Press.

Parsons, T. (1966). Societies: Evolutionary and comparative perspectives. Englewood Cliffs, NJ: Prentice-Hall.

Rosove, P.E. (1972). The interpretation of humanism and educational technology. Educational Technology, 12(1), p. 10-18.

Sartre, J-P. (1977). Life/Situations. New York: Pantheon Books.

Stark, W. (1963). The fundamental forms of social thought. New York: Fordham University Press.

Strauss, E. (1963). The primary world of senses. New York: The Free Press. 